\title{
An integrative framework of technology acceptance model and personalisation in mobile commerce
}

\author{
H.Y. Sonya Hsu
}

Department of Business Systems Analysis and Technology

B.I. Moody III College of Business Administration

University of Louisiana at Lafayette

Lafayette, LA 70504, USA

E-mail: HYHsu@aol.com

\section{Songpol Kulviwat*}

Department of Marketing and International Business

Frank G. Zarb School of Business

222 Weller Hall, 134 Hofstra University

Hempstead, NY 11549-1340, USA

Fax: (516) 463-4834

E-mail: mktszk@hofstra.edu

*Corresponding author

\begin{abstract}
Personalisation has emerged as a key strategy to unlocking the customer's loyalty in mobile service businesses. The objective of the article is to examine customer satisfaction and delight derived from using personalised applications and services in the context of mobile commerce. Results from the survey indicate the amount of generalised messages that customers receive has no effect on either customer satisfaction or customer delight. Further, the preference of multimedia messages and the perceived usefulness of personalised message could increase customer satisfaction, but not customer delight. However, only text messages could make customers satisfied and at the same time could increase customer delight. Implications and avenues for future research are discussed.
\end{abstract}

Keywords: personalisation; mobile commerce; Technology Acceptance Model (TAM); customer satisfaction; delight.

Reference to this paper should be made as follows: Hsu, H.Y.S. and Kulviwat, S. (2006) 'An integrative framework of technology acceptance model and personalisation in mobile commerce', Int. J. Technology Marketing, Vol. 1, No. 4, pp.393-410.

Biographical notes: H.Y. Sonya $\mathrm{Hsu}$ earned her $\mathrm{PhD}$ in Management Information Systems at Southern Illinois University at Carbondale. She has published in the Annual Review of Communication from the International Engineering Consortium and book chapters in Encyclopedia of Knowledge Management, Encyclopedia of e-Commerce, E-Government and Mobile Commerce and Supply Chain Management: Issues in the New Era of Collaboration and Competition. She has also made numerous presentations in national and international conferences. 
Songpol Kulviwat is an Assistant Professor of Marketing and International Business at Hofstra University. He received his $\mathrm{PhD}$ in Marketing from Southern Illinois University. His research interests include internet marketing, high-tech marketing, international business (cross-cultural research) and information technology. His scholarly works have been published or accepted for publication in the Journal of the Academy of Marketing Science, Journal of Internet Research, International Journal of E-Business Research and Asia Pacific Business Review.

\section{Introduction}

The advancement of wireless technology facilitates both consumers' activities and business transactions. With the rapid proliferation and widespread use of mobile devices, including mobile phones, personal digital assistants and handheld computers, mobile commerce (m-commerce) is widely considered to be a driving force for the next generation of electronic commerce. According to a Jupiter Research (Salz, 2005), the Multimedia Media Messaging (MMS) market is expected to be \$US42.5 billion globally in 2005, which is more than double the figure for 2004. Jupiter Research (Earnst-Jones, 2004) further predicted that $\mathrm{m}$-commerce will be an $\$ 88$ billion industry worldwide. However, to date, many promising technologies, especially m-commerce applications, have failed with the notable exceptions of i-mode service and short messaging service. Popular 'i-mode', produced by NTT DoCoMo Company of Japan, is a service that enables wireless web browsing and e-mail from mobile phones. The 'i-mode service' has been the first successful commercial introduction of third-generation mobile applications. The next generation of killer applications for mobile internet is believed to be 'mobile payments' (Van Blokland, 2004). In late December 2003, DoCoMo and KDDI Corporation rolled out the mobile payments system, which can accommodate the shopping payments from virtual shops as well as conventional brick-and-motor shops.

One of the main goals of most operators is building customer satisfaction and loyalty by providing one or more 'killer apps' to their customers. For example, the mobile payment of 3G service has increasingly built over 70 million customers worldwide between DoCoMo and KDDI. Customer Relationship Management (CRM) is one technique that can be integrated into some developed mobile services' applications. In 2005, KDDI strategically allied with Salesforce.com for professionals to download on-demand CRM solutions whenever needed (KDDI, 2005). Recently, the CRM technique became popular for firms that practice customer relationship marketing for the purpose of gaining a competitive advantage. Especially, firms have tried to target these applications to customers on an individualised basis. This may be achieved by 'personalisation'. Personalisation can be regarded as services of the use of technology and user/customer information to customise multimedia content aiming to match with individual needs and ultimately deliver customers' satisfaction. It can be offered by an IP services framework which allows operators and subscribers to use self-service provisioning approaches to control the types of service and applications they want and are willing to buy. 
Given this, no empirical study has fully investigated the personalisation factors that drive customer satisfaction and delight while using mobile applications. This study attempts to utilise the satisfaction and delight for a basis of customer relationship or retention that can be useful for marketing practitioners. With another emphasis on text messaging and multimedia messaging, the researchers intend to integrate the media richness theory along with the technology acceptance theory that advances the interpretation of this research model.

The purpose of this study is to develop a deeper understanding of personalisation with an emphasis on using mobile applications and services that lead to customer satisfaction and delight. Specifically, the paper aims to propose an integrative research framework and empirically test it. The paper is organised as follows: First, the theoretical base underlying the study, which draws on Technology Acceptance Model (TAM) and media richness theory, is developed. Second, the research model and research hypotheses are then presented. Next, the research section describes how the data was collected along with the results of the tests. This is followed by a discussion of the results. Finally, the implications of the results for research and practice are described with the directions for future research.

\section{Literature review and research model}

Figure 1 presents the research model of personalisation in m-commerce. The model is developed based on the TAM (Davis, 1989) and expectancy theory (Oliver, 1977; 1981; 1989). Specifically, this research model extends Ho and Kwok's (2003) research framework. In their pilot study, Ho and Kwok (2003) applied the TAM model originated by Davis (1989) to their m-commerce study. They utilised four constructs to predict the service subscribers' intention to switch: amount of generalised message; perceived ease of use of general advertisements; perceived usefulness of personalised message; and privacy issues about personalised advertisements. To extend the thrust of Ho and Kwok's research, this study attempts to examine the effect of personalisation on customers' satisfaction and delight that could contribute to the principal of customer relationships.

Figure 1 The base model

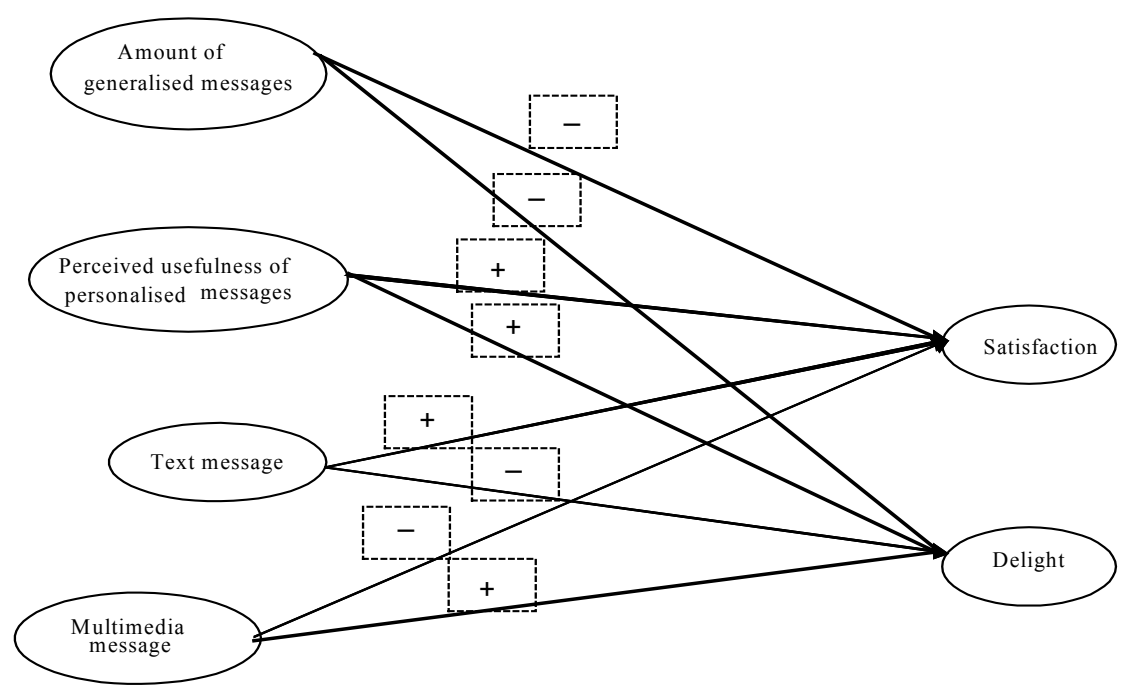




\subsection{Expectancy - satisfaction and delight}

Expectancy theory is used to frame the evaluation of mobile services users. Oliver (1981) defined expectation to include two components: the probability of occurrence (e.g., the likelihood that a personalised cell service will be available) and an evaluation of the occurrence (e.g., the degree to which the personalisation level is desirable or undesirable). The discrepancy of confirmation could be either positive (when performance exceeds the expectations) or negative (when performance is worse off than expected) (Oliver, 1977; 1989).

The highest level of expectation-disconfirmation paradigm is 'customer delight'. The disconfirmation/confirmation paradigm of satisfaction is based on expectancy theory. Customer delight lies primarily within the expectancy disconfirmation paradigm and it can be emotional response to the judgemental disconfirmation between the performance received and the products' or services' normative standards. When the performance and expectations are at variance from each other, it signifies discrepancy. This discrepancy could be positive (when performance exceeds the expectations) which often causes satisfied state. On the other hand, the discrepancy could be negative when performance is worse off than expected (Oliver, 1977; 1981). In other words, a consumer would be satisfied if perceptions match expectations or if confirmations are reached. Consistent with Spreng et al. (1996), satisfaction arises when consumers compare their perceptions of the performance of a good and/or service to both their desires and expectations. As such, satisfaction is a subjective judgement and may imply mere fulfilment (Westbrook and Newman, 1978; Crosby et al., 1990).

Delight is a positive valence state reflecting high levels of consumption-based effect. The feeling of delight is experienced when the customer is pleasantly surprised in response to an experienced disconfirmation. It is the feeling state containing high levels of joy and surprise (Westbrook and Oliver, 1991). Further, Oliver et al. (1997) proposed and confirmed that delight is a function of surprising consumption, arousal and positive affect, or a function of surprisingly unexpected pleasure. They empirically confirmed that delight is a 'mixture' of positive affect and arousal or surprise. It is associated with the level of arousal intensity. Moreover, it is a reaction experienced by the customer at a point of product/good reception. The feeling must go beyond a feeling of satisfaction to provide an unexpected value or unanticipated additional pleasure (Chandler, 1989). In other words, delight occurs when the outcome is unanticipated or surprising. It can be marked by pleasurable, unforgettable and memorable feelings in a service encounter or a product purchase (Verma, 2003). It is thought to be the key to customer loyalty and loyalty-driven profit (Oliver et al., 1997) and is known as the highest level of expectation-disconfirmation paradigm.

Increasing literature has been drawn in the difference between consumer satisfaction and delight (Berman, 2005; Kumar and Olshavsky, 1997; Oliver et al., 1997). To compare satisfaction with delight, Chandler (1989) sees customer delight as being fundamentally different from customer satisfaction. Compared to satisfaction, delight seems more abstract and more extreme in terms of affection. While satisfaction may be induced by avoiding problems or meeting a standard/minimum requirement, delight requires more than that (Oliver et al., 1997). Oliver et al. (1997) empirically confirmed the distinction between the satisfaction and delight constructs, with the delight being a 
higher level of satisfaction. In fact, customer delight is associated with a strong and positive emotional reaction to a product or service. Thus, both practitioners and scholars should manage customer delight as a separate goal from satisfaction.

\subsection{Technology Acceptance Model (TAM)}

From Davis' (1989) TAM model, Perceived Usefulness (PU) and Ease of Use (EOU) of a technology are factors that either directly or indirectly increase a person's intention to adopt an innovation. While perceived usefulness is the degree to which a person believes that using a particular technology/system would enhance the outcome performance, perceived ease of use is the extent to which a person believes that using a particular technology/system will be free of effort (Davis, 1989). TAM could be helpful in predicting the usage of personalised applications and services. Greer and Murtaza (2003) adopted the TAM model in studying issues that impact the valuation of web personalisation as well as factors that determine customer use of web personalisation.

Ho and Kwok (2003) adopted Davis' (1989) PU and EOU of personalised service to test the importance of personalisation in mobile commerce. They found that the PU of personalised service was the most effective factor that affected the decision to change to a new service. Many TAM studies have produced mixed results of the effect of EOU on the dependent variables. Consistent with previous studies, this study focuses on the PU of personalised messages. ${ }^{1}$ As in previous TAM studies, the underlying logic is that the more useful the personalised message is, the more the customers will be satisfied. This should induce a more positive emotional response to the mobile commerce services. This leads to two hypotheses as follows:

\section{Hypothesis la The perceived usefulness of a personalised message has a positive relationship with customer satisfaction.}

Hypothesis $1 b \quad$ The perceived usefulness of a personalised message has a positive relationship with customer delight.

\subsection{Personalisation}

\subsubsection{Description of personalisation}

Personalisation can be defined as the use of technology and user/customer information to customise multimedia content aiming to match with individual needs and ultimately deliver customers' satisfaction (Zhang, 2003). Personalisation is primarily regarded with sending the right message to the right person at the right time. The main goal behind personalisation is to make any medium's usage easier and enhance any channel of communication between customers and service providers (Light and Maybury, 2002).

Personalisation translates individual profiles into unique presentations. The individual profiles can be built upon user preferences, the quality of his or her senses, user location/environment, contexts, users' network and terminal capabilities. Morris-Lee's (2002) study on personalisation of brochures indicated that personalisation helped increase interest and involvement. The production of personalised features costs greater than those that are not personalised (Greer and Murtaza, 2003). Hopefully, these increasing costs associated with personalised features could produce greater customer 
satisfaction and retention and thus, a possibility of a greater return because of customer satisfaction. Also, personalised service has been found to positively impact customers' evaluations of service encounters (Schneider and Bowen, 1999; Brown and Swartz, 1989; Surprenant and Solomon, 1987).

\subsubsection{Personalisation in mobile environment}

In the mobile environment, personalisation is viewed as including "recognition of a customer's uniqueness" (Surprenant and Solomon, 1987, p.87), use of a customer's name (Goodwin and Smith, 1990) and responding to customer needs (Brown and Swartz, 1989). Personalisation can be considered the key factor for success/failure of mobile devices and services (Light and Maybury, 2002).

In addition, the amount of space available on the mobile screen limits the amount of options and information. Information and services must become increasingly tailored to individual user preferences and characteristics in order to accommodate limited space and scarce airtime. Thus, usually when there are too many generalised messages, customers lose their motivation to read, retrieve or even locate a useful message. This leads to two hypotheses as follows:

Hypothesis $2 a \quad$ The more general the message, the more negative its relationship with customer satisfaction.

Hypothesis $2 b \quad$ The more general the message, the more negative its relationship with customer delight.

\subsection{Message format}

Carlson and Davis (1998) characterised medium richness as the capacity to convey information. It is further defined as the ability to provide an immediate feedback to customers' consumption of media. Rich information can be produced by giving immediate feedback, having a variety of available communication cues, understandable or common language and personalisation of the medium (Carlson and Davis, 1998).

Media richness theory postulates that media selection depends on the uncertainty of the task at hand (Kumar and Benbasat, 2002). Both media richness theory and TAM have illustrated their relationships with task orientation. Also, social presence theory postulates a particular communication task based on the degree of necessary social presence that links a selection of media (Kumar and Benbasat, 2002). Social presence seems to be moving towards task-orientation at an individual level in the latter theoretical development, such as the para-social concept from Kumar and Benbasat (2002). Para-social is a combination product of social presence and media richness.

MMS is predicted to be as popular as SMS today. Attractive content is the factor that ultimately drives MMS (Earnst-Jones, 2004); the content can be video, TV programming and gaming (Holden, 2005). MMS, evolving from short messaging (SMS; text messaging), acts like the role of TV and internet today as to newspaper and radio. TV and internet are dominant; however, newspaper and radio still have their market shares. In addition to SMS, companies have increasingly marketed products using MMS to consumers. On the other hand, SMS maintains its market because it was introduced to the 
market earlier and it has been economical to the majority of consumers. As radio and newspaper compete with television, SMS will be used when it is necessary even though MMS has been gaining attention.

Compared to MMS, SMS consumes lower power and capacity and it is easier and faster to send and receive. Mobile ticketing, for example, utilises SMS to issue tickets for movie theaters, parking lots and airlines (Goode, 2006). SMS is short and functional. However, MMS is richer in sound, video and animation. According to Jupiter Research (Earnst-Jones, 2004), the consumer MMS market will remain stronger than the business market. With the differences between satisfaction and delight, we hypothesised richer MMS carries more information that conveys beyond customer satisfaction. MMS intends to bring visual effects to entertain and/or delight customers. SMS, however, transmits enough information to get the 'job' done. For example, SMS can effectively be used to issue a ticket, set an appointment, send a message during a meeting, or deliver an order. Therefore, SMS is a utility tool to complete both business and personal tasks. SMS is more likely to satisfy customers by its utility function. Four hypotheses were developed as follows.

Hypothesis $3 a \quad$ Compared to multimedia messages, text messages are more likely to induce a positive outcome of satisfaction.

Hypothesis $3 b \quad$ Compared to multimedia messages, text messages are more likely to induce a negative outcome of delight.

Hypothesis $4 a \quad$ Compared to text messages, multimedia messages are more likely to induce a negative outcome of satisfaction.

Hypothesis $4 b \quad$ Compared to text messages, multimedia messages are more likely to induce a positive outcome of delight.

\section{Research methodology}

\subsection{Research design}

Participants were solicited from the student population at a large midwestern US university. The participants were students in an introductory management class which included different survey instruments as class materials. Participation was voluntary and confidential in exchange for classes' extra credit. The researchers demonstrated the differences between generalised and personalised messages. The questionnaires were given to participants online via a management class website and they were completed in about ten minutes. Questionnaires were distributed during a three-week period.

There were 200 participants in total. Of these responses, all had web surfing experience and around $78 \%$ had been using the web for more than seven years. More than $80 \%$ of the participants were familiar with a personalised web experience. Fifty-five percent of participants had cell phone services. Only half of them were familiar with personalised messages, mainly because they did not receive many commercial messages 
from vendors, especially in the multimedia format. Approximately 50\% of participants received one to ten text messages; however, the majority of participants $(83 \%)$ never received any multimedia messages.

\subsection{The operationalisation of constructs}

All theoretical constructs were operationalised using previously developed multi-item scales (Appendix). Six constructs were depicted in the research model. Three items used to measure the amount of generalised messages that a person perceived to be receiving were from Ho and Kwok (2003). Also adopted from Ho and Kwok (2003) was the PU of personalised message, which included four items. Text messages included two items and the multimedia message construct was measured with a four-item scale. All the above constructs were measured using seven-point Likert scales ranging from 'strongly disagree' to 'strongly agree'.

For delight, the four-item bipolar adjective scale from Kumar (2004) was used. In this scale, exhilarated, thrilled, excited and delighted were measured on a five-point scale ranging from very little to very much. Oliver et al.'s (1997) delight scale only included two items - arousal and pleasure. However, this study adopted Kumar's (2004) four-item scale because it is likely to be a stronger measure of the construct and was shown to have a higher reliability of 0.94 .

Winsted's (1997) scale of satisfaction, which has a high alpha (0.96) was adopted for this research and was measured using unipolar adjectives. He built upon a scale by Crosby et al. (1990) by adding two more items. The five-item satisfaction scale includes semantic differential scales addressing feelings, pleasure, satisfaction (Crosby et al., 1990), a need-disconfirmation item (Westbrook and Oliver, 1991) and a decision-regret item (Westbrook and Oliver, 1991).

Exploratory Factor Analysis (EFA) was used to analyse the factor structure of the constructs, particularly the satisfaction and delight constructs that received mixed results in earlier literature (Berman, 2005; Schneider and Bowen, 1999). EFA using a principles component with oblique rotations (Oblimin rotation) was performed. Four components were extracted based on prior literature (Ho and Kwok, 2003; Kumar and Benbasat, 2002). Each item loading on these four components has a factor loading higher than 0.70 (Table 1). The first component, 'PU of personalised message', consisted of four items and explained $45.8 \%$ of the variance. The second component, 'multimedia message', included four items and explained $17.6 \%$ of the variance. The third component, 'text message', contained two items and explained $10.06 \%$ of the variance. The fourth component, 'amount of generalised message', had three items and explained $8.46 \%$ of the variance.

The factorability for satisfaction and delight were presented by determinants of correlations matrix (Table 1). The first component, 'satisfaction', had five items and explained $51.04 \%$ of the variance. The second component, 'delight', included four items and explained $35.78 \%$ of the variance. 
Table 1 Factor loadings

\begin{tabular}{|c|c|c|c|c|c|c|}
\hline Items & $\begin{array}{l}\text { Amount of } \\
\text { generalised } \\
\text { message }\end{array}$ & $\begin{array}{c}P U \text { of } \\
\text { personalised } \\
\text { message }\end{array}$ & $\begin{array}{l}\text { Text } \\
\text { message }\end{array}$ & $\begin{array}{l}\text { Multimedia } \\
\text { message }\end{array}$ & Satisfaction & Delight \\
\hline Send many messages & 0.712 & & & & & \\
\hline Too many to read & 0.897 & & & & & \\
\hline Send many ad & 0.842 & & & & & \\
\hline $\begin{array}{l}\text { Like personal } \\
\text { message }\end{array}$ & & 0.923 & & & & \\
\hline Suit needs & & 0.912 & & & & \\
\hline Match needs & & 0.903 & & & & \\
\hline $\begin{array}{l}\text { Reduce time for } \\
\text { searching }\end{array}$ & & 0.786 & & & & \\
\hline $\begin{array}{l}\text { Text message is } \\
\text { suitable }\end{array}$ & & & 0.772 & & & \\
\hline Text is preferable & & & 0.756 & & & \\
\hline Message with music & & & & -0.754 & & \\
\hline Message with picture & & & & -0.857 & & \\
\hline $\begin{array}{l}\text { Message with picture } \\
\text { and audio }\end{array}$ & & & & -0.864 & & \\
\hline Prefer animation & & & & -0.891 & & \\
\hline Satisfied & & & & & 0.871 & \\
\hline Pleased & & & & & 0.907 & \\
\hline Favourable & & & & & 0.888 & \\
\hline Expected & & & & & 0.885 & \\
\hline Happy & & & & & 0.878 & \\
\hline Delighted & & & & & & 0.845 \\
\hline Exhilarated & & & & & & 0.828 \\
\hline Thrilled & & & & & & 0.858 \\
\hline Excited & & & & & & 0.783 \\
\hline
\end{tabular}

\section{Analyses and results}

\subsection{The measurement model}

After the EFA was performed, a Confirmatory Factor Analysis (CFA) using Structural Equation Modelling (SEM) in EQS was used to test construct validity of the multi-item measures used in the present study. To assess the reliabilities of the constructs, Cronbach's alpha and composite/construct reliability estimates (computed from EQS results) were employed. Table 2 shows the reliabilities for each construct shown in the model. All constructs had Cronbach's alphas and construct reliabilities above 0.8 and 0.5 , respectively, which all ranged above the acceptable cut-off values (Nunnally and Bernstein, 1994; Hair et al., 1998). Construct validity was examined via the assessment of each measure's convergent and discriminant validity. Further, several goodness of fit indices (both absolute and incremental fit indices) were used. 
Table 2 Internal consistency reliability/construct reliability of the scale

\begin{tabular}{lcc}
\hline Scales & Reliability $(\alpha)$ & Construct reliability \\
\hline Amount of generalised messages & 0.83 & 0.73 \\
Perceived usefulness & 0.96 & 0.84 \\
Text message & $\mathrm{n} / \mathrm{a}$ & 0.65 \\
Multimedia message & 0.94 & 0.82 \\
Satisfaction & 0.96 & 0.86 \\
Delight & 0.97 & 0.87 \\
\hline
\end{tabular}

The overall goodness-of-fit indices of the Comparative Fit Index (CFI), Non-normed Fit Index (NNFI), Incremental Fit Index (IFI) and Root-Mean-Square Error of Approximation (RMSEA) were 0.96, 0.95, 0.96 and 0.05, respectively, which all exceeded the recommended levels. Also, the chi-square/degrees of freedom of 1.5 was below the threshold. Table 3 presents the summary results of the model fit.

Convergent validity is achieved when the Average Variance Extracted (AVE) between the constructs exceeds 0.5 . Discriminant validity is achieved if an item correlates more highly with items within the same factor than with items in a different factor. Table 4 shows that both convergent and discriminant validity were met. Only two correlations of satisfaction and delight that are highly correlated, however, are consistent in the literature (Oliver et al., 1997). Taken together, the fit indices, reliabilities and AVE suggest excellent measures and constructs.

Table 3 Summary statistics of model fit

\begin{tabular}{lcccc}
\hline Fit indices & Threshold $^{*}$ & $\begin{array}{c}\text { Measurement } \\
\text { model }\end{array}$ & $\begin{array}{c}\text { Structural model } \\
\text { (Base model) }\end{array}$ & $\begin{array}{c}\text { Structural model } \\
\text { (Revised model) }\end{array}$ \\
\hline$\chi^{2} /$ d.f. & $(\leq 3)$ & 1.50 & $\mathrm{n} / \mathrm{a}$ & $\mathrm{n} / \mathrm{a}$ \\
CFI & $(\geq 0.9)$ & 0.96 & 0.92 & 0.94 \\
NNFI & $(\geq 0.9)$ & 0.95 & 0.91 & 0.93 \\
IFI & $(\geq 0.9)$ & 0.96 & 0.92 & 0.94 \\
RMSEA & $(\leq 0.08)$ & 0.05 & 0.07 & 0.06 \\
\hline
\end{tabular}

Notes: *The threshold values indicate the model's acceptable level of fit.

$\chi^{2} /$ d.f. $=$ Chi-square/degree of freedom

$\mathrm{CFI}=$ Comparative Fit Index

NNFI = Non-normed Index

IFI $=$ Bollen Fit Index

RMSEA = Root Mean Square Error of Approximation

Source: See Hu and Bentler (1999) 
Table 4 Convergent and discriminant validity matrix*

\begin{tabular}{lcccccc}
\hline Construct & $\begin{array}{c}\text { Amount of } \\
\text { generalised } \\
\text { message }\end{array}$ & $\begin{array}{c}\text { PU of } \\
\text { personalised } \\
\text { message }\end{array}$ & $\begin{array}{c}\text { Text } \\
\text { message }\end{array}$ & $\begin{array}{c}\text { Multimedia } \\
\text { message }\end{array}$ & Satisfaction & Delight \\
\hline $\begin{array}{l}\text { Amount of } \\
\text { generalised } \\
\text { messages }\end{array}$ & 0.58 & 0.13 & 0.02 & 0.23 & 0.11 & 0.16 \\
$\begin{array}{l}\text { Perceived } \\
\text { usefulness }\end{array}$ & 0.02 & 0.70 & 0.54 & 0.36 & 0.43 & 0.40 \\
$\begin{array}{l}\text { Text } \\
\text { message }\end{array}$ & 0.00 & 0.29 & 0.60 & 0.44 & 0.30 & 0.41 \\
$\begin{array}{l}\text { Multimedia } \\
\text { message }\end{array}$ & 0.05 & 0.13 & 0.19 & 0.66 & 0.35 & 0.33 \\
$\begin{array}{l}\text { Satisfaction } \\
\text { Delight }\end{array}$ & 0.01 & 0.18 & 0.09 & 0.12 & 0.67 & 0.81 \\
\hline
\end{tabular}

Notes: *Diagonal elements (italic) represent the average variance extracted between the constructs. The numbers above the diagonal elements are the correlations between the constructs. The numbers below the diagonal elements are the shared variances (or squared correlations) among constructs. For discriminant validity, diagonal elements should be larger than off-diagonal elements.

\subsection{Structural model analyses}

Structural Equation Modelling (SEM) technique using EQS was implemented to test the proposed research model and hypotheses. The significance of path coefficients in the model provides support for hypothesised relationships (Bentler, 1989). The overall model was examined using multiple fit indices. The base model provides acceptable initial incremental and absolute fit indices of CFI, IFI, NNFI and RMSEA, which were 0.92, 0.92, 0.91 and 0.07, respectively (see Table 3) (Hu and Bentler, 1995; Hu and Bentler, 1999).

However, a model fit could be further improved as suggested by the Wald and Lagrange mulitiplier (LM) tests. Specifically, the LM test points to parameters and paths that could be added to the model in order to improve fit. Based on prior theoretical reasoning, the test suggests adding two paths to the revised model which are: from perceived usefulness of personalised messages to multimedia message and from satisfaction to delight. Overall fit of the revised model is excellent, with CFI, IFI, NNFI and RMSEA of 0.94, 0.94, 0.93 and 0.06, respectively (see Table 3).

EQS was used to estimate the coefficients for each of the paths in the revised model. Figure 2 presents the revised model and structural path coefficients for each relationship. The data supported most of the individual causal paths postulated by the proposed research model. As predicted, perceived usefulness of a personalised message was a significant determinant of customer satisfaction, thus supporting Hypothesis 1a $(\beta=0.26$, $\mathrm{p}<0.01)$. However, it was not a significant determinant of customer delight and thus not supporting Hypothesis $1 \mathrm{~b}(\beta=$ n.s. $)$. The results are somewhat in line with other TAM studies (Ho and Kwok, 2003). Further, a suggested path given by LM test which linked perceived usefulness to multimedia message was added. This was found to be significant $(\beta=0.36, \mathrm{p}<0.01)$. 
Figure 2 Revised theoretical model and testing results

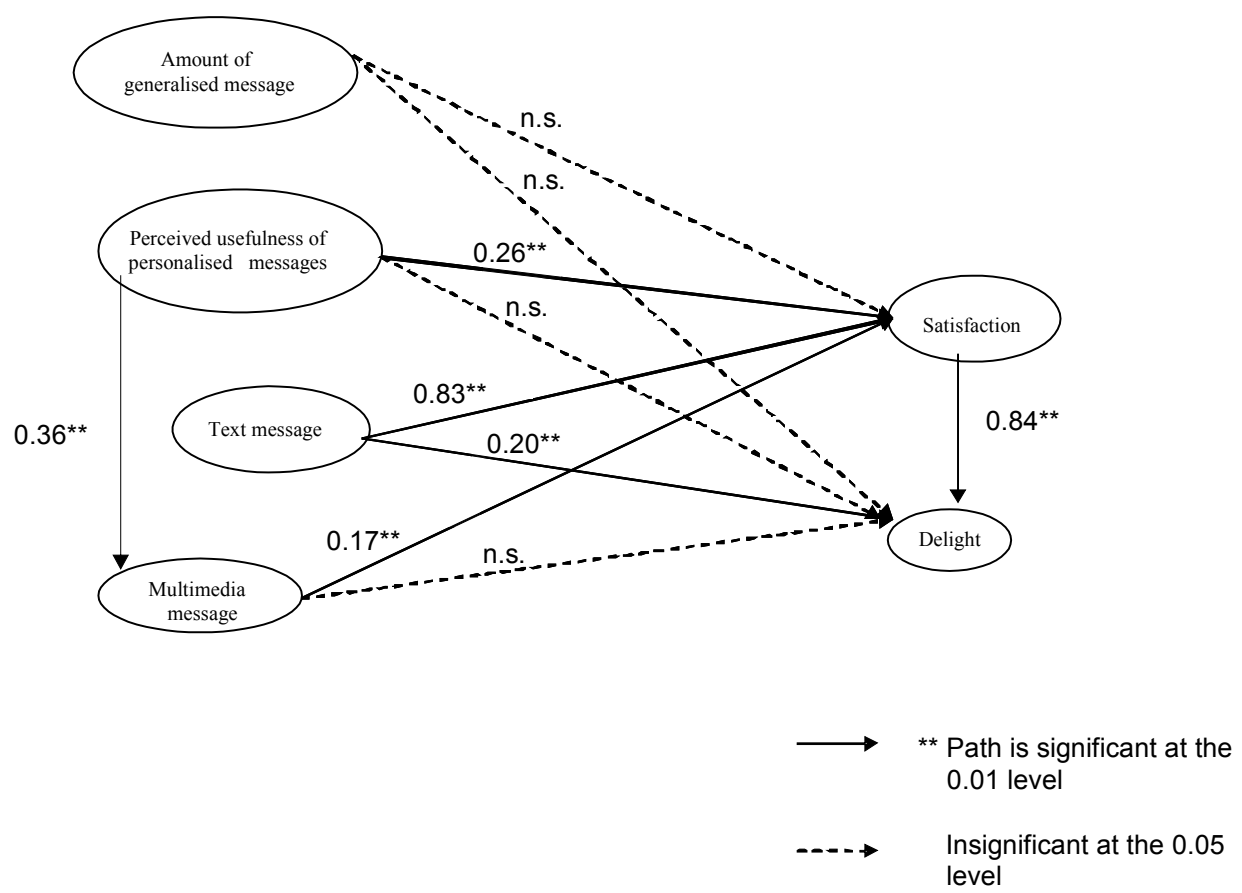

Hypotheses $2 \mathrm{a}$ and $2 \mathrm{~b}$ related the amount of generalised messages to customer satisfaction and delight. The amount of generalised messages that customers receive has neither an effect on customer satisfaction in Hypothesis $2 \mathrm{a}(\beta=\mathrm{n}$.s.) nor customer delight in Hypothesis $2 b$ ( $\beta=$ n.s.), thus not supporting Hypotheses $2 a$ and $2 b$.

Hypotheses $3 \mathrm{a}$ and $3 \mathrm{~b}$ pertained to text messages. The analysis indicated significant effects of text messages on satisfaction $(\beta=0.83, p<0.01)$ and delight $(\beta=0.20$, $\mathrm{p}<0.01)$. It showed that the text messages could make customers satisfied and at the same time could increase customer delight. Although both relationships were found to be significant, these are partially supported since the hypothesised relationship of text message to delight was opposite from previously hypothesised. Hypotheses $4 \mathrm{a}$ and $4 \mathrm{~b}$ pertained to multimedia messages. The results showed that the preference of multimedia messages increased opposite from the hypothesised direction for customer satisfaction ( $\beta=0.17, p<0.01)$ but not customer delight $(\beta=$ n.s.). Further, as suggested by LM test, an added link between satisfaction and delight was found to be strongly significant $(\beta=0.84, p<0.01)$ which is consistent with the existing literature.

\section{Discussion}

The amount of generalised messages that customers received had no influence on either customer satisfaction or customer delight. Despite the fact that respondents had little experience with commercial message in a multimedia format, it had a positive association with customer satisfaction. On the other hand, text messaging is adequate enough to 
handle day-to-day problem-solving/information needs and satisfy customers or even delight them. Hence, the personalisation of messages is an important tool especially for marketing and campaign managers. However, it was suggested that the formats to deliver these messages are equally important based on those results.

Contrary to our expectation, the amount of generalised messages was not related to customer satisfaction and delight. According to Santos and Boote (2003), even though satisfaction and delight are two different constructs, it serves as a dimension of confirmation (satisfaction) at one end and disconfirmation (delight) on the other end. At the present time, most owners could specify the messages that interested them so the amount of spam sent is dramatically reduced. The other end is that the feeling of annoyance at receiving generalised messages is not strong enough to induce dissatisfaction or disconfirmation. However, it is clear that mobile phone service managers should focus on personalised services technology to attract more customers rather than sending more general advertisements/messages to customers. Hence, the generalised messages may not have any effects expected by campaign managers.

Perceived usefulness of personalised message could only make customers satisfied and could not induce user's feeling of delight. The PU of personalised message is robust and is comparable to PU used in TAM model. This result is consistent with Ho and Kwok (2003) who found that the PU of personalised service was the most significant factor affecting the decision to change to a new service. In TAM, PU induces either positive attitude or user intention to system/technology acceptance or adoption. Thus, it is appropriate to broaden the TAM model by substituting attitude/intention with expectancy (satisfaction and delight) as perceived usefulness of personalised message induces direct impact on both expectancy outcomes.

The EOU of personalised messages was intended to be tested. However, it was collapsed with PU of personalised messages. The reasons might have been caused by the following operationalisation of the constructs:

- The distinction between personalised and generalised which was not explained in Ho and Kwok's (2003) study.

- The respondents may have been confused between generalised and personalised messages when answering those questions.

- The EOU of personalised message may not have been defined well enough for the participants.

Most importantly, the EOU of personalised messages may not be a concern when it comes down to retrieving message from a cell phone or making use of commercial messages. In the end, the cell phone is a simpler technology than the computers or programs in any previous TAM research.

The results partially supported the idea that preference for multimedia messages increased customers' satisfaction with current cell phone service, even though the majority of participants did not have any experience with commercial messages in a multimedia format. It was more likely based on participants' preferences in this situation. Compared to text messages, multimedia messages might not be familiar to the audiences at the present time. Further, at the end, the participants are more familiar to the text message and may still focus on context rather than pictures and/or sounds. In fact, a 
majority were not willing to pay the premium (or they could not afford) to use multimedia. The function of using mobile service (e.g., cell phone) is mainly for convenience and emergency.

\subsection{Implications for practice}

Practitioners should be cautioned that most consumers or users may not yet be sophisticated enough to expect what is ahead of them. On the other hand, consumers would like to have richer media to experience 'delight'. This echoes the principle of media richness (Carlson and Davis, 1998) which states that the more complex media formats can deliver more information in a message. If campaign or advertising managers would like to increase effectiveness and/or efficiency of a campaign, text messages would be a necessary tool. However, this might not be sufficient enough for sophisticated consumers or so-called high-tech consumers. Thus, customer bases must be segmented into distinct groups so that appropriate strategies can be designed and tailored to match such particular segments.

Besides personalisation, multimedia formats can be a supplemental tool to increase the interaction with consumers when launching an advertising campaign. The richer the media, the more effective it is in communication (Short et al., 1976; Kahai and Cooper, 2003). Media richness theorists also emphasise the effect of 'immediate feedback' to customer's responses. Some may argue that personalisation is a kind of immediate feedback (Kahai and Cooper, 2003). However, if campaign managers would like to increase customers' loyalty, 'sequential immediate feedback' (Kahai and Cooper, 2003) may be required.

\subsection{Implications for research}

In this study, the test of 'media richness' was not quite as successful for the following reasons:

- The student population has not experienced multimedia enough to give answers to specific questions.

- The multimedia format from the cellular service providers is not sophisticated enough because of narrow bandwidth, slow data download and low physical security for the public to pay a premium price other than the so-called 'innovators' or 'gadgets'.

- The multimedia format may include more than just the conveyed-information but expand to 'the marketing side of media richness', such as interactive marketing (Zahay and Griffin, 2003).

Interactivity can be referred to as responses to customers, taking into account a customer's individual response to prior communication. Te'eni et al. (2001) used three dimensions to define media richness further and they are interactivity, adaptiveness and channel capacity. Beyond a different format from a text message, future researchers may look into a deeper understanding of multimedia messages that convey information for customers' delight in addition to satisfaction. Delightedness can be marked as pleasurable, unforgettable and memorable where customer loyalty is rooted (Verma, 2003; Oliver et al., 1997). 
One limitation of this study is that a student population was used. Future research may investigate professional groups that have the reasons to use mobile commerce and/or a population that has more disposable income at hand. Another limitation of this study that can be addressed in the future is the sophistication of multimedia services and the maturity of users. In other words, future researchers may look into some markets that have rolled out mMode of AT\&T, Mobile Web of Verizon and/or Sprint's PCS.

From a mobile application point of view, 'personalisation' can be more sensitive to users' needs, such as the location-based application in www.mobull.usf.edu. Local merchants work together to deliver personalised text message, such as sales, promotion advertisement and coupons, from a website to a wireless device based on personal preferences that are set up by each individual. Location-based services utilise location information to provide specialised contents to mobile users (Varshney, 2003). According to ethic standards in the industry, explicit user permissions should be obtained before 'pushing' any advertising content (Varshney, 2003). Push and pull advertisement, relates to the issues of privacy and sharing of user information. Therefore, the 'trust' matter may surface between a group of local merchants and individual consumers.

The research model in this study intends to be parsimonious in mobile commerce. Although the roles of trust and culture are important in TAM (Straub and Keil, 1997; Gefen et al., 2003), very little research has augmented influences of trust and different (sub)culture, such as different professions and different countries, from TAM in m-commerce research. Future research should replicate and extend TAM to empirically test the role of trust. Further, future research could also compare the TAM model across different professions/countries in m-commerce. By doing so, the TAM model's predictive power will be richer. It would also be interesting to incorporate the works of Moore (1999) and the life cycle model of technology intensive products and their markets into the research model to further enrich the knowledge in this area.

\section{References}

Bentler, P.M. (1989) EQS: Structural Equations Program Manual, version 3.0., Los Angeles: BMDP Statistical Software Inc.

Berman, B. (2005) 'How to delight your customers', California Management Review, Vol. 48, No. 1, pp.129-151.

Brown, S.W. and Swartz, T.A. (1989) 'A gap analysis of professional service quality', Journal of Marketing, Vol. 53, No. 2, pp.92-98.

Carlson, P.J. and Davis, G.B. (1998) 'An investigation of media selection among directors and managers: from "self" to "other" orientation', MIS Quarterly, Vol. 22, No. 3, pp.335-362.

Chandler, C.H. (1989) 'Beyond customer satisfaction', Quality Progress, Vol. 22, No. 2, pp.30-32.

Crosby, L.A. and Stephens, N. (1987) 'Effects of relationship marketing on satisfaction, retention, and prices in the life insurance industry', Journal of Marketing Research, Vol. 24, No. 4, pp.404-411.

Crosby, L.A., Evans, R.K. and Cowles, D. (1990) 'Relationship quality in services selling: an interpersonal influence perspective', Journal of Marketing, Vol. 54, pp.68-81.

Davis, F.D. (1989) 'Perceived usefulness, perceived ease of use and user acceptance of information technology', MIS Quarterly, Vol. 13, No. 3, pp.319-339.

Earnst-Jones, K. (2004) 'MMS evolution', Juniper Research, http://www.juniperresearch.com/ pdfs/white_paper_MMS2.pdf (accessed on 2 February 2006). 
Gefen, D., Karahanna, E. and Straub, D.W. (2003) 'Trust and TAM in online shopping: an integrated model', MIS Quarterly, Vol. 27, No. 1, pp.51-90.

Goode, A. (2006) 'Ticketing goes mobile', Juniper Research, http://www.juniperresearch.com/ pdfs/white_paper_mcommerce2.pdf (accessed on 2 February 2006).

Goodwin, C. and Smith, K.L. (1990) 'Courtesy and friendliness: conflicting goals for the service provider?', Journal of Services Marketing, Vol. 4, No. 1, pp.5-21.

Greer, T.H. and Murtaza, M.B. (2003) 'Web personalization: the impact of perceived innovation characteristics on the intention to use personalization', Journal of Computer Information Systems, Vol. 43, No. 3, pp.50-55.

Hair, J.F., Anderson, R.E., Tatham, R.L. and Black, W.C. (1998) Multivariate Data Analysis with Readings, 5th ed., Englewood Cliffs, NJ: Prentice-Hall.

Ho, S.Y. and Kwok, S.H. (2003) 'The attraction of personalized service for users in mobile commerce: an empirical study', ACM SIGecom Exchanges, Vol. 3, No. 4, pp.10-18.

Holden, W. (2005) 'TV on the move', Juniper Research, http://www.juniperresearch.com/pdfs/ white_paper_mobiletv.pdf (accessed on 2 February 2006).

Hu, L. and Bentler, P.M. (1995) 'Evaluating model fit', in R. Hoyle (Ed.) Structural Equation Modeling: Issues, Concepts, and Applications, CA: Sage, pp.76-99.

Hu, L. and Bentler, P.M. (1999) 'Cutoff criteria for fit indexes in covariance structure analysis: conventional criteria versus new alternatives', Structural Equation Modeling, Vol. 6, No. 1, pp.1-55.

Kahai, S.S. and Cooper, R.B. (2003) 'Exploring the core concepts of media richness theory: the impact of cue multiplicity and feedback immediacy on decision quality', Journal of Management Information System, Vol. 20, No. 1, pp.263-299.

KDDI (2005) KDDI and Salesforce.com Announce Strategic Partnership to Deliver On-Demand Mobile CRM Solution for the Japanese Market, http://www.kddi.com/english/corporate/ news_release/2005/0613/index.html (accessed date: 31 January 2006).

Kumar, A. (2004) 'Conceptualizing customer delight and an empirical test of its consequences', Working Paper.

Kumar, A. and Olshavsky, R. (1997) 'Distinguishing satisfaction from delight: an appraisal approach', Paper Presented at the Annual Conference of the Association for Consumer Research, AZ: Tucson.

Kumar, N. and Benbasat, I. (2002) 'Para-social presence and communication capabilities of a web site a theoretical perspective', e-Service Journal.

Light, M. and Maybury, M.T. (2002) 'Personalized multimedia information', Communications of the ACM, Vol. 45, No. 5, pp.54-59.

Moore, G. (1999) 'Crossing the chasm: marketing and selling high-tech products to mainstream customers', Harper Business.

Morris-Lee, J. (2002) 'Custom communication: does it pay?', Journal of Database Marketing, Vol. 10, No. 2, pp.133-138.

Nunnally, J.C. and Bernstein, I. (1994) Psychometric Theory, 3rd ed., New York: McGraw-Hill.

Oliver, R.L. (1977) 'Effects of expectation and disconfirmation on post-exposure product evaluations: an alternative interpretation', Journal of Applied Psychology, Vol. 62, No. 4, pp.480-486.

Oliver, R.L. (1981) 'Measurement and evaluation of satisfaction processes in retail settings', Journal of Retailing, Vol. 57, pp.25-48.

Oliver, R.L. (1989) 'Processing of the satisfaction response in consumption: a suggested framework and research propositions', Journal of Consumer Satisfaction, Dissatisfaction and Complaint Behavior, Vol. 2, pp.1-16.

Oliver, R.L., Rust, R.T. and Varki, S. (1997) 'Customer delight: foundations, findings, and managerial insight', Journal of Retailing, Vol. 73, No. 3, pp.311-336. 
Salz, P.A. (2005) 'Mobile content commerce', EContent, Vol. 28, No. 4, p.24.

Santos, J. and Boote, J. (2003) 'A theoretical exploration and model of consumer expectations, post-purchase affective states and affective behavior', Journal of Consumer Behavior, Vol. 3, No. 2, pp.142-157.

Schneider, B. and Bowen, D.E. (1999) 'Understanding customer delight and outrage', Sloan Management Review, Vol. 41, No. 1, pp.35-45.

Short, J., Williams, E. and Christie, B. (1976) The Social Psychology of Telecommunication, NY: John Wiley \& Sons.

Spreng, R.A., Mackenzie, S.B. and Olshavsky, R.W. (1996) 'A reexamination of the determinants of consumer satisfaction', Journal of Marketing, Vol. 60, pp.15-32.

Straub, D. and Keil, M. (1997) 'Testing the technology acceptance model across cultures: a three country study', Information and Management, Vol. 33, No. 1, pp.1-12.

Surprenant, C.F. and Solomon, M.R. (1987) 'Predictability and personalization in the service encounter', Journal of Marketing, Vol. 51, No. 2, pp.86-96.

Te'eni, D., Sagie, A., Schwartz, D.G., Zaidman, N. and Amichai-Hamburger, Y. (2001) 'The process of organizational communication: a model and field study', IEEE Transactions on Professional Communication, Vol. 44, No. 1, pp.6-21.

Van Blokland, A. (2004) 'Killer apps from DoCoMo and KDDI', J@pan Inc., Vol. 53, p.6-6.

Varshney, U. (2003) 'Wireless I: mobile wireless information systems: applications, networks, and research problems', Communications of the Association for Information Systems, Vol. 12, pp.155-166.

Verma, H.V. (2003) 'Customer outrage and delight', Journal of Services Research, Vol. 3, No. 1, pp.119-133.

Westbrook, R.A. and Newman, J.W. (1978) 'An analysis of shopper dissatisfaction for major household appliances', Journal of Marketing Research, Vol. 15, pp.456-466.

Westbrook, R.A. and Oliver, R.L. (1991) 'The dimensionality of consumption emotion patterns and consumer satisfaction', Journal of Consumer Research, Vol. 18, pp.84-91.

Winsted, K.F. (1997) 'The service experience in two cultures: a behavioral perspective', Journal of Retailing, Vol. 73, No. 3, pp.337-360.

Zahay, D. and Griffin, A. (2003) 'Information antecedents of personalization and customization in business-to-business service markets', Journal of Database Marketing, Vol. 10, No. 3, pp.255-271.

Zhang, D. (2003) 'Delivery of personalized and adaptive content to mobile devices: a framework and enabling technology', Communications of AIS, Vol. 12, No. 13, pp.183-204.

\section{Note}

1 In this present study, the same scale of PU is collapsed with EOU of generalised message construct (see Table 1). 


\section{Appendix Measurements of constructs}

\begin{tabular}{lll}
\hline Construct & Measurement of Construct & Source \\
\hline $\begin{array}{l}\text { Amount of generalised } \\
\text { messages }\end{array}$ & - Send many messages & Ho and Kwok (2003) \\
& - Send many advertisement & \\
& - Too many to read & \\
$\begin{array}{l}\text { Perceived usefulness of } \\
\text { personalised message }\end{array}$ & - Like personalised message & Ho and Kwok (2003); \\
& - Suit needs & Davis (1989) \\
& - Match needs & \\
& - Reduce time for searching & \\
Text message & - Text message is suitable & Carlson and Davis (1998); \\
& - Text message is preferable & Kumar and Benbasat (2002) \\
Multimedia message & - More fun with music & Carlson and Davis (1998); \\
& - Prefer message with picture & Kumar and Benbasat (2002) \\
& - Message with audio and pictures & \\
& - Prefer animation & \\
Satisfied, pleased, favourable, & Winsted (1997); Oliver (1981; \\
& expected and happy & $\begin{array}{l}\text { 1989); Crosby and Stephens } \\
\text { (1987); Crosby } \text { et al. (1990) }\end{array}$ \\
& $\begin{array}{l}\text { Delighted, exhilarated, } \\
\text { thrilled, excited }\end{array}$ & Oliver et al. (1997) \\
\hline
\end{tabular}

